\title{
Study on the Gradient and Difference of the Anthropology of Music and Ethnomusicology in the Perspective of Epistemology
}

\author{
Linhan $\mathrm{Yu}^{1, \mathrm{a}}$ \\ ${ }^{1}$ Art Institute, Wenshan University, Wenshan, Yunnan, China, 663000 \\ a email
}

Keywords: Epistemology, Ethnomusicology, The Anthropology of Music, The Gradient, The Difference

\begin{abstract}
From the beginning of the New World discovery, the Anthropology of Music and ethnomusicology began to have a gradual process of derivatives and gradually differentiate in their field of study. From the perspective of epistemology and cognition, this paper describes ethnomusicology, the Anthropology of Music gradients and their study and research perspective differences. This not only shows the dialysis of the academic discipline and research purposes focus more clearly, but also to characterize the Ethnomusicology and The Anthropology of Music in discipline development nowadays already mature.
\end{abstract}

\section{Introduction}

Ethnomusicology is the study of the world by various ethnic music system find the special laws of each national music development throughout the world and universal law. The Anthropology of Music as a cultural phenomenon, to study human behavior and social attributes from the popular culture Phenomena.

Epistemology is to explore the nature of human cognition, structure, cognitive objective reality of the relationship between the premise and basis for understanding, understanding occurs, the law of the development process and its philosophical doctrine, recognizing the truth of standards and other issues. Materialist epistemology stick from matter to consciousness awareness course, that the material world is an objective reality, emphasizing the understanding of human reflection of objective reality, affirming world can be met. Dialectical materialism epistemology further understanding of the practice as a basis for the dialectics applied epistemology. [1] scholars generally believe that any understanding of a subject, are required to start from the research methods, research object, feature, purpose, objectives and disciplines derived sources five areas of its interpretation. From the perspective of the epistemological point of view, and The Anthropology of Music has its own unique process of gradual change in the course of its development in the field of Music Theory Ethnomusicology. Whether or ethnomusicology The Anthropology of Music, are inseparable from the study and discussion of subjects Methodology gradient pattern.

\section{The Gradient of Anthropology of Music and Ethnomusicology}

Gradient is a strong regularity diachronic evolution phenomenon, which can be used in visual design have a strong sense of perspective and a sense of space, showing a kind of order, there is a change of pace. In fact, the same is true in the domain of musicology. The Anthropology of Music and Ethnomusicology academic gradual process derived from the domain of musicology reflects a certain gradual process. Since Columbus discovered the New World, a large number of European settlers, missionaries, ethnologists, anthropologists have been in Asia, Africa, America and other regions began to examine these areas of history, culture. As a common concern of mankind music, dance and other art have become interested in their particular domain. French writer Montaigne book "cannibalism barbarian tribes," describes the Brazilian heat Rio de Janeiro beach a small island in Native American folk barbarians. On the open, its research methods and other European music Concept Music Views areas are for comparison. In fact, introducing musical culture in Asia, Africa, America and other regions in the academic theory of self-evident domination, music and 
music theory in these areas in Europe for comparison, such as "American barbarians custom Rafi pottery - customs relatively primitive times, "the French official diplomatic Dayton" About oriental music - compared with European music "and other works had begun comparative musicology, the nineteenth century laid the foundation for the birth of comparative musicology. In my opinion, now in a lot of paper as long as it comes to Ethnomusicology, scholars agree that the comparative musicology Ethnomusicology from the gradient, not knowing The Anthropology of Music is also derived from the disciplines of comparative musicology. Of course, these three disciplines in succession to each other when Recommend colonial music is also a gradual process. Western music by the Renaissance Center and Its Influence, 1885 A.J Ellis's "On the scale of States" opened the door Comparative Musicology. Then, at T. Bartok and C. Adams with Schwarzkopf and others efforts, comparative musicology in Europe has been considerable development and improvement. However, with the musical elements geographical displacement academic areas, Asia, Africa, America and other regions of the New World was also the academic knowledge, comparative musicology discipline has been a challenge. The main sign is 1900, E.M.V Horn Post Ethnomusicology Haier group of scholars will use the term explicitly into their works. In the treatise, they proposed the establishment of the discipline and culture Ethnomusicology distinguished scholar responsible for the establishment of Ethnomusicology Conception domain task. Although Ethnomusicology name when it is just created "comparative musicology", but these scholars virtually comparative musicology Ethnomusicology as a research approach to look, rather than discipline. In Europe, the cultural center on domination, Asia, Africa and the New World outside Europe Distinct and extensive musical matters as their object of study.

In fact, in 1955 Ethnomusicology will be set up, a number of scholars and experts in anthropology background to Ethnomusicology studies to enable them to start or ethnology and anthropology, or start music studies start eventually became the "cross in musicology and ethnology (anthropology) on the dividing line," the amphibious scholar [2]. There Anthropology these scholars believe that the essence of Ethnomusicology of human culture and the various ethnic groups to create human culture research is not enough. For in-depth study of human culture, they made a research culture in the perspective view of musicology. Merriam (A.P. Merriam) of "The Anthropology of Music" a book published is a sign of its birth. Merriam in his book: "There is a The Anthropology of Music, the music is in the range of sociologists and anthropologists to learn music is concerned, it provides the basis for all the tone generation, and ultimately understand those and tone. sound framework process far as anthropology is concerned, it helps to learn more about the human life of the product and the process, because the music is a complex act of human intelligence factor. nobody's thinking, behavior and creativity, there will be no tone ; and now we want to understand more than the sound of the whole process of generation of the musical understanding. "[3] obviously, Melilla Khayyam" the Anthropology of emergence Music "book foreshadowed the Anthropology of Music in Ethnomusicology from the official. On the subject domain is derived become an independent discipline. Some people think that since Melilla Khayyam "The Anthropology of Music" a book appears, Ethnomusicology "to the music of" phenomenon began. In the author's view, this is a sign of The Anthropology of Music and Ethnomusicology gradient performance in the discipline of epistemology, is both the essence of differentiation. In contrast, as a foreign subject, Ethnomusicology and The Anthropology of Music penetration in Chinese understanding and also has a gradual process, not a sudden. Compare learned music is from Ethnomusicology and then to The Anthropology of Music Development and evolution. Usually scholars believe, Ethnomusicology into China is Wang Guangqi "A Comparative Study of Chinese and Western music system," a text for the beginning of the beginning. I think, under the tutelage of Wang Guangqi Horn Post Haier scholars studying in Germany, by the German "Berlin School of Music" musical influences thought, the "comparative musicology" the discipline of philosophy indeed brought China, the comparator Musicology take root in China. Xiao Youmei, Liu and Yang Yinliu days of various scholars in this discipline under the guidance of the methodology for the study of Chinese folk music a lot, and laid the comparative musicology academic foundation in China. In 1980, Mr. Wing thick high advocated "national Ethnomusicology 
Symposium" held in Nanjing Arts Institute, officially "Ethnomusicology" The subject name put on the academic agenda. Scholars. Due to many new music matters to attract a large number of different academic backgrounds to participate in Ethnomusicology studies, [4] and therefore there has been flourishing situation. At the same time, this subject is also the breeding ground for many of the outstanding issues. With the advent of Melilla Khayyam "The Anthropology of Music" book, Chinese scholars about The Anthropology of Music and Ethnomusicology debate more intense. Some people think that the last decade we stir The Anthropology of Music in essence, Ethnomusicology, is another title of Ethnomusicology. In the author's view, that would not necessarily. Ethnomusicology Musicology and Ethnology is a combination of discipline, The Anthropology of Music is a combination of music and anthropology discipline. Although the cultural background of their meaning and, these two different names represent the same scope of the study, but the research point of view, research methods and research purposes are two different disciplines. [5]

\section{The Difference of Anthropology of Music and Ethnomusicology}

Needless to say, from the perspective of the epistemological point of view, the behavior of European colonial world for the study of ethnic music culture laid the foundation of all ethnic music compared with the rise of European musical culture of comparative musicology discipline play a role in fueling. With the expansion of comparative musicology research vision of a kind of ethnology and musicology combination of new subjects appeared to study them all nationalities music and music culture of responsibility. Another music and anthropology combining discipline emerged as a musical phenomenon of human Mappings people, behavior and culture created by human beings as its mission. Of course, in the academic development and the gradual process of understanding, they can not exist without discipline differentiation, derived from the fact that the gradient.

Professor Luo Qin said: "What The Anthropology of Music is what I think, or rather, The Anthropology of Music is a concept, a way of thinking and an idea .The Anthropology of Music music as an object, from the special perspective to understand themselves, he created his social and cultural as is the wish of the complex phenomenon of music have a deeper understanding, to know the notes behind the bears something more essential to close to human life in general or universal "truth". [6] the Anthropology of Music from the date of differentiation of musical culture as put their research destination, so research groups around the world of music is the Anthropology of Music culture Music house Khayyam mission as Merry said:. the Anthropology of Music is also a subject of study in the world music culture of all human things like music refraction under [7].

Ethnomusicology everything music as the object of their own research, by studying the world's various ethnic music system find the special laws of each national music development throughout the world and universal law. In the author's opinion, music is a spiritual cultural phenomenon, is humanity to express thoughts and feelings, exchange of information and the creation and selection, to tone and noise for the performance of the media and the carrier, acts beyond words function outside of a system the way. Ethnomusicology the music itself, and music system throughout the world as its object of study. Ethnomusicology in their subject domain of the study of world music and cultural background research body is without prejudice. This discipline is generally defined as: "Search through various forms of academic music made for all cultures of the world in different forms, the objectivity of research."

Professor Qin Luo thought: "Ethnomusicology" scholars focused on the study of Chinese traditional music, focusing on the analysis form, from the music itself to find links between cultural factors, and the end result constitutes research varied music itself; and " the Anthropology of Music "relates to the field relative to some broader, more attention to music (including forms) occurs, and the reasons for the existence of the constitution, to find factors influencing music from cultures foothold in asking" how people make music. " [8] In the author's opinion, Ethnomusicology and The Anthropology of Music are two different research areas under purport to lead, along with the development and refinement of discipline nowadays, the two are interrelated in distinguished. 
Since the discovery of the New World, the Comparative Study of European academic music for music in Asia, Africa, America and other regions with their region, the formation of comparative musicology. With the refinement of disciplines, academic vision comparative musicology expanding gradually to all regions of the world music culture and music system things like refraction as its object of study. The Anthropology of Music and Ethnomusicology two camps tend to differentiate from the academic theory and practice, and ultimately the formation of two separate types of discipline. Professor Du Yaxiong in "Introduction to Ethnomusicology" clearly stated "The Anthropology of Music and Ethnomusicology is the study of methods and scope of the study is very similar discipline, but because of their different emphases, they are completely different disciplines." [9]. Professor Luo Qin "music culture and music culture," a book clearly states that "the notes is recorded music notation, musical tone is composed musical instruments, the sound is only music carriers, music and real carrier he is a man of culture. " [10]

\section{Conclusion}

Study the gradient and difference of Ethnomusicology and The Anthropology of Music from the epistemological aspects, , so that future generations not only in the study of the subject and object of focus of understanding more clearly, but also reflects the Ethnomusicology and The Anthropology of Music nowadays discipline development has matured.

\section{References}

[1] Zhang Dongsun. Epistemology [M]. Commercial Press, 2011: 17.

[2] Li Xiaobing. Ethnomusicology the Essence Music Cultural Interpretation [J]. Shandong Art College (Qilu Yiyuan) 2007 (1): 61-65.

[3] Tang Yating. The Western Historical Ethnomusicology Conservatory Thought Development [J]. Chinese Music 1999 (2): 44-63.

[4] Yang Minkang. From Methodology to National Philosophy: Transformation of Modern Ethnic music theory and hierarchical [J]. Chinese Music (Quarterly) 2006 (3): 15-22.

[5] Henry Louis • Morgan. Ancient Society [M]. Zhang Kurihara, M. Beijing: People's Literature Publishing House .1957: 2.

[6] Liao Mingjun. Relationship between music and culture, what - Qin Luo Interview [J]. National Art 2001 (2): 44-59.

[7] Melilla Mariam. The Anthropology of Music [M]. Mu Ming Qian interpret Road School Beijing: People's Music Publishing House 2010: 13.

[8] Luo Qin. Ethnomusicology, or The Anthropology of Music-- On the subject of translation problems and understanding the "Resolution" and select [J]. Music of 2012 (5): 49-60.

[9] Du Yaxiong. Ethnomusicology Introduction to [M]. Shanghai: Shanghai Conservatory of Music Publishing .2011: Introduction 2; 5.

[10] Luo Qin. Review music culture and the culture of music (revised edition) [M]. Shanghai: Shanghai Music Publishing House 2010: Author Preface. 